\title{
Tarihsel Eleştiri Yöntemlerinin İslami Rivayetlere Uygulanma İmkânına Dair Bazı Mülâhazalar*
}

Araștırma makalesi / Research article

Fatma Betül ALTINTAŞ ${ }^{* *}$

Some Remarks on the Application of Historical Criticism to Islamic Traditions

Citation/@: Altıntaş, Fatma Betül, (2019). Some Remarks on the Application of Historical Criticism to Islamic Traditions, Milel ve Nihal, 16 (2), 279-304.

Abstract: Historical Criticism is an umbrella term for methods which include source, form, redaction and tradition criticism aiming to evaluate and critically understand the texts by considering its origins, sources, the time and the place in which the text was written. The historical criticism methods that emerge from the Western tradition under the influence of Greek-Roman and Jewish-Christian traditions suggest to look at the texts from historical perspective due to the temporal and spatial differences that interfere with the commentator. These methods which have emerged as an outcome of many processes and changes in many fields, have been applied in the most intense and most systematic way on Bible texts. In time, historical criticism began to be applied on other texts of different religions and cultures. While some of these applications are capable of achieving very valuable results for some, for others it is unthinkable to apply these methods to the texts of foreign religions and cultures. In this study -considering its philosophical foundations, basic features, pre-assumptions and approaches to texts- the possibility of applying historical critical methods on Islamic traditions will be emphasized.

Keywords: Historical Critical Methods, Islamic Traditions, Historicism, Biblical Criticism.

* Bu makale, 2019 yılında tamamladığımız "Tarihsel Eleştiri Yöntemlerinin Tenkidi ve İslami Rivayetlere Uygulanması Sorunu" başlıklı doktora tezi esas alınarak hazırlanmıştır.

** Arş. Gör. Dr., Erciyes Üniversitesi, İlahiyat Fakültesi, Hadis Anabilim Dalı [fatmazehrabetul@gmail.com] ORCID: 0000-0002-9814-5472. 
Atıf/C: Altıntaş, Fatma Betül, (2019). Tarihsel Eleştiri Yöntemlerinin İslami Rivayetlere Uygulanma İmkânına Dair Bazı Mülâhazalar, Milel ve Nihal, 16 (2), 279-304.

Öz: Tarihsel eleştiri yöntemleri, metinleri menşei, yazılış zamanı, yazılış mekânı ve kaynaklarını dikkate alarak değerlendirmeyi ve eleştirel bir biçimde anlamayı amaçlayan yöntemler manzumesidir. Yunan-Roma ve Yahudi-Hıristiyan geleneklerin tesiri altındaki Batı geleneği içerisinden neşet eden tarihsel eleştiri yöntemleri, yorumcu ile araya giren zamansal ve mekânsal farklılık sebebiyle metinlere tarihsel perspektiften bakmayı önerir. Birçok olay ve sürecin neticesinde ortaya çıkmış olan ve zaman içinde değişikliklere uğrayan bu yöntemler, en yoğun ve en sistematik şekilde Kitab-ı Mukaddes metinleri üzerinde uygulanmıştır. Zamanla tarihsel eleştiri yöntemleri farklı dinlerin ve kültürlerin önemli metinleri üzerinde de denenmeye başlanmıştır. Bu uygulama denemeleri kimileri açısından çok değerli sonuçlara ulaştırabilecek özellikte iken kimilerine göre ise bu yöntemlerin yabancı din ve kültürlerin metinlerine uygulanması asla düşünülemez. Bu çalışmada kaynak, form, redaksiyon ve gelenek/rivayet tenkidi gibi farklı türleri olan tarihsel eleştiri yöntemlerinin felsefî temelleri, temel özellikleri, ön kabulleri ve metinlere yaklaşımları göz önünde bulundurularak İslâmî rivayetler üzerinde uygulanmasının imkânı meselesi üzerinde durulacaktır.

Anahtar Kelimeler: Tarihsel Eleştiri Yöntemleri, İslami Rivayetler, Tarihsellik, Kutsal Kitap Tenkidi.

\section{Giriş}

Toplumlar açısından önemli kabul edilen metinlerin sonraki nesillere bozulmadan aktarılması, gerçekleşen bozulma varsa bunların tespiti ve düzeltilmesi ile aktarılan metinlerin doğru anlaşılması ve yorumlanabilmesi konusunda tarih boyunca birçok gelenek çeşitli boyutlarda katkı sağlamıştır. Metinlerin aktarılması ve anlaşılması konusunda Batı medeniyetinin ${ }^{1}$ katkılarından kabul edilebilecek tarihsel eleştiri yöntemleri, daha çok metinlerin nerede, ne zaman, kim tarafından yazıldığı; metnin formu ve değeri ile ilgilenen ileri tenkit yöntemleri (İng: Higher Criticism) arasında yer alır. ${ }^{2}$

Metinlerin tarihlendirilmesi ve orjinalinin tespiti ile metnin yorumlanması ve anlaşılmasına katkı sağlamak üzere iki işleve sahip

1 Bu makalede kullanılan "Batı medeniyeti (Batı)" kavramı ile Avrupa ve Kuzey Amerika ülkeleri ile bunların geçmişi kabul edilebilecek Roma ve Yunan uygarliklar kastedilmektedir.

2 Andrew Constantinides Zenos, The Elements of the Higher Criticism (Funk \& Wagnalls Company, 1895), 15. 
Tarihsel Eleştiri Yöntemlerinin İslami Rivayetlere Uygulanma İmkânına Dair... olan tarihsel eleştiri yöntemleri, kaynak tenkidi (İng: Source criticism), form tenkidi (İng: Form Criticism), redaksiyon tenkidi (İng: Redaction Criticism) ve gelenek/rivayet tenkidinden (İng: Tradition Criticism) oluşur. Bu yöntemler metinlere uygulandığında ilk olarak metnin kaynakları keşfedilir. Daha sonra form tenkidi ile insan tecrübelerinin şifahî olarak ifade edildiği farklı edebî biçimler (ağıt, ilâhî, efsane vb.) göz önünde bulundurularak metni oluşturan parçalar tespit edilir. Redaksiyon tenkidi ile yazarlar veya redaktörlerin metin üzerinde nasıl değişiklikler yaptıkları ortaya konulur. Gelenek/rivayet tenkidi ile ise rivayetlerin doğası ve bunların toplumun tarihi için nasıl kullanıldığı incelenir. ${ }^{3}$

Tarihsel eleştiri yöntemleri Rönesans ve Reform hareketleri ile doğmuş ve Aydınlanma ile yaygınlık kazanmıştır. ${ }^{4}$ Tarihsel eleştiri yöntemleri, evvela Antik metinlerin de içerisinde yer aldığı tarihî ve edebî metinlere uygulanmıştır. Buralardan elde edilen tecrübelerin de katkısı ve farklı süreçlerin de etkisi ile ${ }^{5}$ bu yöntemler Kitab-1 Mukaddes metinleri üzerinde uygulanmaya başlamıştır. Bu yöntemlerin en uzun süreli ve en sistematik şekilde uygulandığı metinler Kitab-1 Mukaddes metinleri olmuştur. ${ }^{6}$ Modern tarih biliminin de doğması ile bu yöntemler dini olmayan metinler ile birlikte daha geniş çaplı tarihsel metinler ve süreçler üzerinde de uygulanmıştır.

Tarihsel eleştiri yöntemleri, özünde tarihselliği kabul eden yöntemlerdir. En genel anlamiyla, bir olayı, olguyu ya da durumu hem çevresel şartlar hem de geçmişin durumunu ve şartlarını göz önünde bulundurarak değerlendirmeye tarihsellik denir. Tarihsellik terimi ile doğrudan alakalı olan tarihselcilik (İng: Historicism Alm:

3 John H. Hayes - Carl R. Holladay, Biblical Exegesis: A Beginner's Handbook (Atlanta: John Knox Press, 1982), 77,85,94; Richard N. Soulen, Handbook of Biblical Criticism (Louisville: Westminster John Knox Press, 2001), 61, 159, 178, 198.

4 David R. Law, The Historical-Critical Method: A Guide for the Perplexed (Bloomsbury Publishing, 2012), 25-26.

5 Antik metinlere uygulanan yöntemlerin kutsal kitaba da uygulanabileceği düşüncesi, Rönesans ve Reform ile literal yorumun ve "sadece Kutsal Kitap" (Lat: Sola scriptura) görüşünün ön plana çıkması, metinleri orijinal dilleriyle anlamak gerektiği düşüncesi, 'Tarihsel İsa' araştırmalarının ilgi görmesi, şüpheciliğin ön plana çıkması, tarih ve tarih yazımı ile ilgili kabul ve yöntemlerde meydana gelen değişiklikler, tarihî ve arkeolojik kanıtların değerli görülmeye başlanması, anlamla ilgili metin, yazar veya okuru merkeze alan teorilerin ön plana çıkması gibi gelişmeler bunlardandır.

6 David E. Aune, The Blackwell Companion to the New Testament (John Wiley \& Sons, 2010), 103. 
Historismus) ise durumları ve olayları anlamanın doğru yolunun, durum ve olayların tarihlerini veya bu olayların gerçekleştiği bağlamın tarihini anlamaktan geçtiğini savunan akımdır. ${ }^{7}$ Tarihselcilik, tarihsel bilginin değerini merkeze alan bir düşünce sistemi ve tarihsel bilginin nasıl elde edileceğine dair bir bilgi eleştirisi olarak tanımlanabilir. ${ }^{8}$ Burada, tarihselciliğin problemli görülen yönlerinin eleştirilmesi, bu problemlerin aşılmaya çalışılması amacıyla değişiklikler oluşması neticesinde ortaya çıkan farklı versiyonları üzerinde durmak gerekir. Tarihselciliğin primitif versiyonu, modern Aydınlanma felsefesinin bilimsel metot ve deterministik açılama konusundaki düşkünlüğüne bir reaksiyon olarak, insan yasalarının doğa yasaları gibi olmadığı; insanın yaşamı ve toplumun tarihsel olarak anlaşılması gerektiği üzerinde yaptığı vurgu ile ortaya çıkmıştır. ${ }^{9}$ Fakat ortaya çıktığı günler itibarıyla bu düşüncenin Aydınlanma'nın etkisinden tam olarak kurtulması mümkün olmamış, çizgisel bir tarih anlayışı benimsenmiş ve insan tarihin üstünde bir bakış açısına sahip süper bir güç olarak tanımlanmaya devam etmiştir. Burada tarihsellik, anlamın üzerinde bir sis perdesi kabul edilmiş, bu açıdan tarihsel olan şey artık geçmişte kaldığı için anlaşılır görülmemiştir. ${ }^{10}$ Tarihselciliğin ikinci versiyonu ise yorumsamacı tarihsellik anlayışıdır. Bu versiyonda insan tarih ile maluldür, tarih üstü değildir. Heidegger'le başlayıp Gadamer'le ilerleyen bu anlayışa göre tarihselcilik varlığın varoluş imkânıdır. Burada tarihsellik primitif versiyondaki gibi anlamaya engel teşkil eden bir durum değil, olumlu bir durumdur. ${ }^{11}$ Burada ayrıca bir de tarihselciliğin üçüncü bir versiyonundan bahsetmek gerekir. Bu tarihselciliğe, öngörücü tarihselcilik ya da tarihsicilik ismi verilir. Tarihsicilik, Popper'a

7 Jonathan Rée - James Opie Urmson, The Concise Encyclopedia of Western Philosophy and Philosophers (Routledge, 2005), 159.

8 Bekir Geçit, Erich Rothacker ve Karl R. Popper'de Tarihselcilik Problemi, (Doktora Tezi, Mersin Üniversitesi, 2015), 3.

9 Byron Kaldis, Encyclopedia of Philosophy and the Social Sciences (Sage Publications, 2013), 420.

10 Şevket Kotan, "Kur'ân'ın Tarihselciliği Tartışması" İslâmî İlimler Dergisi I. Kuran Sempozyumu (İslâmî İlimler Dergisi Yayınları, 2007), 49; Doğan Özlem, "Felsefî Hermeneutiğe Geçiş Yolu Olarak Tarihselcilik", Ankara Üniversitesi Illahiyat Fakültesi Dergisi 1/40 (1999): 136.

11 Yasin Aktay, "Kur'an Tarihselciliğine Bir Soykütüğü (Geneology) Denemesi", Kur'anı Anlamada Tarihsellik Sorunu Sempozyumu (İstanbul: KURAV, 2000), 33; Kotan, “Kur'ân'ın Tarihselciliği Tartışması", 49. 
Tarihsel Eleştiri Yöntemlerinin İslami Rivayetlere Uygulanma İmkânına Dair...

göre, tarihin evriminin temelinde yatan ritimler ve örüntüler, kanunlar ve yönelimlerin açı̆̆a çıkarılmasıyla varılabileceğini kabul eden bir yaklaşımdır. Tarihselciliğin bu türünü "kötü tarihselcilik" olarak adlandırmasında görüldüğü gibi, bu anlamdaki tarihselcilik genellikle negatif anlamda kullanılmaktadır. Burada bir kadercilik ve kehanetçilik vardır. ${ }^{12}$

Reform hareketlerine kadar, kutsal metinlerle ilgili kilisenin doğru kabul ettiği ve çoğunlukla dogmaları ispat eden yorumlar geçerli görülmüştür. Reform hareketleri ile birlikte kilisenin yorum yetkisi tartışmaya açılmış, metin ile okuyucunun arasına giren zamana dikkat çekilerek kilisenin yorumlarının güncellenmesi, eleştirel bir şekilde ve tarihsellik unsurunu da göz önünde bulundurarak yeniden incelenmesi gerektiği üzerinde durulmuştur. Buna göre bir metnin orijinal anlamı ortaya çıkarmak için, yorumcu ile metin arasındaki tarihsel mesafe ve metnin ortaya çıkmasına neden olan tarihî şartlar göz önünde bulundurulmalıdır. Bu işlemler adeta yorumların basamak basamak geri götürülmesi suretiyle, bir nevi arkeolojik kazı yapar gibi, metnin en erken halindeki orijinal anlamının yeniden ortaya çıkarılmaya çalışılmasıdır. ${ }^{13}$ Kilisenin yorumlarına yönelik bu eleştirel bakış, kutsal metinlerle ilgili tarihsellik tartışmalarının ortaya çıkmasına vesile olmuştur. Bununla birlikte, bu eleştirel bakış, içerisinde doğduğu zamanın bilimselci-rasyonalistnesnelci anlayışından da etkilenmiştir. Bu açıdan, Kutsal Kitap tenkidi çalışmaları, tarihselliğin primitif versiyonu ile bilimselci-rasyonalist-nesnelci anlayışa bulanmış olarak, kartezyen nesnelci ideolojinin eşliğinde doğmuştur. Buna göre kutsal kitabın tarih sürecinin dışında kalıp tarihe tarih dışından bakabilecek "süper insan" sayesinde ve olağanüstü anlatımların ortadan kalkması ile nesnel şekilde okunması ve anlaşılması mümkündür. ${ }^{14}$ Bununla birlikte, tarihsel eleştiri yöntemlerinin temel kabul ettiği tarihselcilik anlayış1nın yukarıda da bahsi geçtiği gibi zaman içinde farklılaşması ile birlikte yöntemler pozitivist ve kuralcı karakterini azaltıp yorumsamacılığa doğru kaymıştır.

12 Richard Kroner, "Tarih ve Tarihsicilik", Tarih Incelemeleri Dergisi 25/2 (2015): 638; Karl R Popper, "Sunuş", Tarihselciliğin Sefaleti, çev.: Sabri Orman (1998), 25. Tarihselciliğin bu formları arasındaki ayrımla ilgili olarak ayrıca bknz: Nevzat Tartı, Tarihsellik Düşüncesi ve Hadislerin Anlaşılması (Ankara: Otto, 2016), 17-30.

13 Law, The Historical-Critical Method, 15; Stanley E. Porter, Dictionary of Biblical Criticism and Interpretation (London; New York: Routledge, 2007), 359.

14 Aktay, "Kur'an Tarihselciliğine Bir Soykütüğü (Geneology) Denemesi", 30. 
İlk olarak tarihî ve edebî metinler üzerinde tarihsel eleştiri yöntemlerinin dini metinler üzerinde kullanımının imkânı, esasında Batı dünyasında da tartışılmıştır. Yöntemlerin kutsal metinler üzerinde uygulanmasına özellikle Katolikler uzun süre karşı çıkmışlardır. 1546'da Trent Konsilinin bu yöntemlerin dini metinlere uygulanamayacağ 1 ve yorumlamada tek geçerli otoritenin kilise olduğunu belirtmesine rağmen uygulama girişimleri devam etmiştir. İlk dönemlerde yöntemlerin kullanılması kilisenin tepkisini çekse de daha sonra uygulamaların "zarar"larını en aza indirmeye çalışmak amacıyla yönteme en büyük katkıyı beklenmedik şekilde Katolikler yapmaya başlamıştır. 1943'te Divinio Afflante Spiritu tamimi ile ise H1ristiyanlığa hizmet amaciyla Kitab-1 Mukaddes üzerinde bu yöntemlerin kullanılmasına resmen izin verilmiştir. ${ }^{15} \mathrm{Bu}$ süreç içerisinde, tarihsel eleştiri yöntemlerine birçok açıdan eleştiriler yöneltilmiş, yöneltilen bazı eleştiriler uygulama denemelerinde yapılan yeniliklerle aşılmaya çalışılmıştır. Bu açıdan tarihsel eleştiri yöntemlerinin Batı'daki kullanımı, sürekli bir değişim içerisinde olmuştur. ${ }^{16}$

Farklı gelenekler tarafından geliştirilmiş metodolojik araçların farklı geleneklerin metinleri üzerinde kullanılıp kullanılamayacağı tartışmalı bir konudur. Bu tartı̧̧malar, tarihsel eleştiri yöntemlerinin farklı geleneklere ait metinlere uygulanması konusunda da yapılmıştır. Yukarıda değinildiği gibi, ilk etapta dini olmayan metinler için geliştirilmiş yöntemlerin dini metinler üzerinde kullanımı problemi tartışılmışken, sonraki dönemlerde uygulamaların yaygınlaşması ile tarihsel eleştiri yöntemlerinin Kitab-ı Mukaddes dışındaki dini metinler üzerinde de uygulamalar yapılabileceği savunulmuş ve bu yönde çeşitli denemeler de yapılmıştır. ${ }^{17}$

15 Soulen, Handbook of Biblical Criticism, 21.

16 Bu açıdan tarihsel eleştiri yöntemlerine Avrupa'nın dönüşen yapılarıyla paralel ilerleyen eleştirel bir "süreç" olarak yaklaşmak gerektiğine dair öneriler anlamlı görünmektedir. Duran, Aydınlanma ve Kutsal Kitap, 17.

17 Bu yöndeki görüşler ve uygulamalar için bk. Raymond B. Williams, "Historical Criticism of a Buddhist Scripture: 'The Mahāparinibbāna Sutta'", Journal of the American Academy of Religion 38/2 (1970): 157; Williams, "Historical Criticism of a Buddhist Scripture"; Paul Griffiths, "Buddhist Jhāna: A form-critical study", Religion 13/1 (1983): 55-68. 
Tarihsel Eleştiri Yöntemlerinin İslami Rivayetlere Uygulanma İmkânına Dair...

Tarihsel eleştiri yöntemlerinin İslâmî rivayetler ${ }^{18}$ üzerindeki ilk denemeleri XVIII. yüzyılın sonu ve XIX. yüzyılın başında Oryantalistler eliyle gerçekleştirilmiştir. ${ }^{19}$ Hatta oyantalistlerin İslami rivayetler üzerindeki tüm çalışmaları ve uygulamaları, bu yöntemlerin farklı düzeylerdeki iz düşümleri kabul edilebilir. Bu uygulamalar çoğu zaman metinlerin anlaşılması ya da yorumlanmasından ziyade tarihlendirilmesi amacıyla olmuştur. Bu dönem, İslam dünyasının gücünün zayıfladığı, oryantalizmin yükseldiği, Avrupa-merkezci hegemonik bakışın hâkim olduğu ve yöntemlerin Kitab-1 Mukaddes üzerindeki uygulamalarında dahi Pozitivizm gibi ideolojilerin yoğun olarak hissedildiği bir dönemdir. Bu açlardan yöntemlerin İslâmî rivayetler üzerinde denenmesi, olumsuz bir tecrübe olarak başlamıştır.

Tarihsel eleştiri yöntemleri, yaygın olmamakla birlikte, İslâmî rivayetler üzerinde Müslüman isimler tarafından da uygulanmıştır. Genel olarak dini metinlere tarihsel yaklaşımı benimsediğini söyleyebileceğimiz Tâhâ Hüseyin (ö. 1973), ${ }^{20}$ Fazlurrahman (ö. 1988), ${ }^{21}$

18 Bu çalışmada "İslâmî rivayet" tabiri ile, tarihsel eleştiri yöntemlerinin uygulandığı veya uygulanma potansiyeline sahip olan, hadis, tefsir, İslam tarihi alanlarındaki tüm rivayetler kast edilmektedir.

19 Bu uygulamalarla ilgili ayrıntılı bir liste için bk. Fatma Betül Altıntaş, Tarihsel Eleştiri Yöntemlerinin Tenkidi ve İslâmî Rivayetlere Uygulanması Sorunu (Doktora Tezi, Erciyes Üniversitesi, 2019), 251-255; Ahmet Yücel, Oryantalist Hadis Literatürü (İstanbul: İfav, 2016).

20 Tâhâ Hüseyin, Fi'ş-Şi'ri'l-Câhilî adlı eserinde tarihsel eleştiri yöntemlerini Cahiliye dönemi şiirlerine tatbik etmiştir. Tâhâ Hüseyin, şiirlerde bulunan İslami unsurlardan hareketle bu şiirlerin İslam döneminde yazılıp önceki döneme atfedildiğini iddia ederek Cahiliye şiirinin İslâmî döneme intikalini ve kimi Cahiliye şairlerinin mevcudiyetini neredeyse bütünüyle reddetmiştir. Şükran Fazlıŏlu, “Taha Hüseyin”, Dİ (İstanbul: Türkiye Diyanet Vakfı, 2010); Peter E. Pormann, "Classics and Islam: From Homer to al-Qāida", International Journal of the Classical Tradition 16/2 (2009): 197.

21 Kur'an'ın, "ikili hareket yöntemi" ile anlaşılması ve yeniden yorumlanması gerektiği üzerinde duran ve bu yöntemin aynı zamanda sünnetin anlaşılmasında da kullanılabileceğini ifade eden Fazlurahman'ın bu yöntemi sünnetin anlaşılmasında kullanılabilmesini söylemesi, onun "yaşayan sünnet" anlayışı ile alakalıdır. Fazlurrahman'a göre "yaşayan sünnet" Nebevî sünnetin spesifik durumlara bağlı olarak yorumu, elden geçirilmesi ve uyarlanmasını da içeren Ümmet'in icmasının bir uzantısıdır. Fazlurrahman'a göre yaşayan sünnete, şekilci ve lafızcı hadis uygulamaları ile ulaşılamaz. Bu sebeple, hadislerdeki çeşitli unsurlar yeniden değerlendirilmeli, hadisler durumsal bağlamları içerisinde incelenmeli ve gerçek fonksiyonel önemi anlaşılmaya çalışılmalıdır. Bu ise hadisleri “yaşayan 
Arkoun (ö. 2010) ${ }^{22}$ ve Hasan Hanefi ${ }^{23}$ gibi isimler, bu yöntemlerin İslâmî rivayetler üzerinde kullanımının mümkün ve uygun (hatta gerekli) olduğu üzerinde durmuşlardır. ${ }^{24}$

Yöntemlerin İslami rivayetler üzerinde uygulanması gerektiğine dair görüş bildiren bu isimlerden Tâhâ Hüseyin (ö. 1973), tarihsel eleştiri yöntemlerini Cahiliye şiirine uygulamıştır. Arkoun, Kur'an'a ve İslam düşüncesi üzerinde uygulamalar yapmış fakat İslâmî rivayetler üzerinde herhangi bir denemede bulunmamıştır. Fazlurrahman (ö. 1988) ve (ö. 2010) ve Hasan Hanefî ise yöntemleri Kur'an ve İslam düşüncesi üzerinde olduğu gibi İslâmî rivayetler üzerinde de uygulanması gerektiğini ifade etmiş ve bu yönde de uy-

sünnet"e indirgemek ve onda var olan gerçek değeri tarihî şartların gerekli k1ldığı arka plandan açıkça ayırmak suretiyle mümkündür. Tarihsel eleştirel yaklaşım, Fazlurrahman açısından tam olarak bu fonksiyonu icra etmektedir. Fazlurrahman, Tarih Boyunca İslâmî Metodoloji Sorunu, çev.: Salih Akdemir (Ankara: Ankara Okulu Yayınları, 1997), 81-87; Daniel Brown, İslam Düşüncesinde Sünneti Yeniden Düşünmek (Ankara: Ankara Okulu, 2009), 162-168.

22 Dini metinleri tarihselci bir okumaya açan Arkoun, oryantalistlerin Hz. Peygamber'in biyografisine filolojik ve tarihselci eleştirinin yıpranmış yöntemini uygulamakta olduklarını vurgulamaktadır. Arkoun, hadisler için de tarihsel eleştiriyi önermektedir. Fakat Arkoun'un teklifi herhangi bir uygulamaya geçirilmiş görünmemektedir. Arkoun'un yöntemlerin hadisler üzerindeki uygulanışı ile ilgili teklifi hadislerin yazımının geç bir tarihte tamamlanmış olduğuna dair fikri ile bağlantılıdır. Ona göre bu gecikme metinlere yansıyarak Sünnîler, Şiîler ve Hariciler arasında tartışmaya neden olmuştur. Bunun için söz konusu üç geleneğin getirdiği metinlerin aslına uygunluk sorununu yeniden ele alacak çağdaş bir soruşturma yöntemi kullanılarak (metinlerdeki verilerin bilgisayarla tarihlendirilmesi) tarihsel eleştiri yapılmalıdır. Mohammed Arkoun, İslam Üzerine Düşünceler, çev.: Hakan Yücel (İstanbul: Metis Yayınları, 1999), 58-62.

23 Hasan Hanefî, "et-Türâs ve't-Tecdîd" projesi kapsamında, geleneğe olan yaklaşımın nasıl olması gerektiği üzerinde dururken, geleneğin toptan kabul edilmesi, toptan reddedilmesi, geleneğin ve modernliğin uzlaştırılması gibi yaklaşımlar yerine önerdiği yaklaşımda tarihsel eleştiriye yer vermektedir. Ona göre, geleneğin tarihte toplumun ihtiyacına uygun üretilmiş bir başarı olduğu kabul edilmelidir. Fakat tarihî tenkit yöntemi ile geleneğin ilerici yönlerini ortaya çıkarmalı ve bu yönleri asrın ihtiyaçlarına göre ön plana çıkarak gerekmektedir. Yani kadim gelenek tarihsel eleştiri ile tenkit edilmeli, geleneğin ileri yönlerinden yeniden bir gelenek inşasına girişilmelidir. Hasan Hanefi, Gelenek ve Yenilenme, çev.: Emin Maşalı (Otto, 2011), 32-42; İlhami Güler, “Hasan Hanefî'nin Tecdid Projesi -Tanıtım ve Bir Değerlendirme-", İslâmî Araştırmalar 7/2 (1994): 151-152.

24 Burada ele alan isimler, tarihsel eleştiri yöntemlerinin uygulanması gerekliliği üzerinde açık beyanda bulunmuş isimlerdir. 
Tarihsel Eleştiri Yöntemlerinin İslami Rivayetlere Uygulanma İmkânına Dair... gulamalarda bulunmuşlardır. Bununla birlikte bu uygulamalar, rivayetin söylenişinin sosyal-siyasi bir bağlamla ilişkilendirilmesinin ardından basit bir şekilde reddinden ibaret kalmıştır. ${ }^{25}$

Oryantalistlerin uygulamalarıyla başlayan bu olumsuz tecrübeye ve İslâm dünyasının net bir sonuca ulaşamamış ve birçok eleştiriye uğramış bu denemelerine rağmen, bu yöntemlerin metodolojik açıdan istifade edilebilecek evrensel yönlerinin bulunup bulunmadığı sorusu üzerinde durulması gerekir. Bu soruya cevap bulabilmek için ise öncelikle yöntemlerin metodolojilerine yöneltilen eleştiriler ile İslâmî rivayetler üzerindeki uygulamalara yönelik daha özel eleştirilerin gözden geçirilmesi gerekmektedir. Ancak bu eleştirilerle hesaplaşmak mümkün olursa yöntemlerin halen vaad edebileceği bir şey olup olmadığı tartışmasını sürdürmek anlamlı olur. Zira bu yöntemlerle ilgili tartışmalar genellikle bilimsel bir yaklaşımdan uzak şekilde ve polemikler üzerinden gerçekleştirilmektedir. Oysa bu konuya bilimsel bir çerçevede bakmakta, görüşleri ve bunlara yöneltilen itirazları anlamaya çalışmakta yarar vardır. Bu ihtiyaçtan hareketle bu çalışmanın amacı, söz konusu yöntemlerin zayıf noktalarının, sınırlılıklarının, çelişkileri içeren yöntemlere yönelik metodolojik eleştirileri göz önünde bulundurarak, İslâmî rivayetler üzerinde kullanımının imkanını tartışmaktır.

Bunun için öncelikle, tarihsel eleştiri yöntemlerinin İslâmî rivayetler üzerinde kullanımına dair tartışmalar üzerinde durmak gerekir.

\section{Yöntemlerin Farklı Metinler Üzerinde Kullanımının İmkânına Dair Tartışmalar}

Tarihsel eleştiri yöntemlerinin İslâmî rivayetler üzerinde kullanılması konusunda, uygulamayı mümkün görmeyen ve görenlerin dile getirdikleri çeşitli argümanları vardır. Yöntemlerin İslâmî rivayetler üzerinde kullanılamayacağına dair dile getirilen en temel gerekçe, bu yöntemlerin her türlü metne uygulanabilecek evrensel yönlerinin bulunmadığı iddiasıdır. Buna göre, bu yöntemlerin kökeninde Batı geleneğinin insana kâinata ve varlığa dair kabullerinin izleri mevcuttur ve bu her türlü uygulamaya yansıyabilir. Bu görüşü kabul edenlere göre, bu yöntemlerin evrensel olduğu görüşünün temelinde, yöntemlerin içinden neşet ettiği Batı'nın inceleme

\footnotetext{
25 Bu uygulamalar hakkında ayrıntılı bilgi için bk. Altıntaş, Tarihsel Eleştiri Yöntem-
} lerinin Tenkidi ve İslâmî Rivayetlere Uygulanması Sorunu, 289-298. 
nesnesi olarak gördüğü diğer din ve kültürlerin, kendi din ve kültürleri ile aynı aşamalardan geçtiğini düşünmeleri yatmaktadır. Yani bu düşünceye göre, bütün din ve kültürlerin geçtiği aşamalar evrenseldir. Bu sebeple bu "evrensel yöntemler", "evrensel" aşamaları geçen tüm din ve kültür metinlerine uygulanabilir. ${ }^{26}$ Yine bu görüşe göre, bu yöntemler mevzudan ve değerlerden arınmış yöntemler değildirler. Yöntem denilen şey mevzuya bağlıdır. Yani her yöntem her mevzuya tatbik edilemez, eğer israrla tatbik edilirse mevzu asliyetini kaybeder ve yeniden tanımlanması gerekir. Eğer mevzu dönüşürse, bu yöntemin başarısı olsa bile sosyal değişime yol açmaya başlar. Varoluş ve varlık değiştiği zaman da asıl ile irtibat kopmuş olur. ${ }^{27}$

Tarihsel eleştiri yöntemlerinin İslâmî rivayetler üzerinde kullanılmasının imkânsız olduğuna dair dile getirilen diğer bir gerekçe Batı ile İslam dünyası arasında var olan paradigma farkıdır. Bu görüşe göre, tarihsel eleştiri yöntemleri, Aydınlanma'nın bir ürünüdür ve modern paradigmalarla yoğrulmuştur. Bu paradigma, evrenin merkezinde Tanrı'nın değil (sadece maddî bir varlık olarak) insanın yer aldığı, rasyonel, materyalist, pozitivist ve faydacı bir paradigma olarak tanımlanabilir. Bu paradigmalar, Batı dışı toplumlarda realiteyi yorumlama ve değiştirme sürecine katkıda bulunmaz, aksine bu süreci zehirler. Yani Batı paradigmasında ortaya çıkan bu yöntemlerin İslâmî rivayetlere uygulanması fayda yerine zarar verir. Çünkü ithal edilmiş, çoğunlukla epistemolojik sonuçlarına ilişkin köklü bir bilgiye bile sahip olunmaksızın benimsenen yabancı paradigmalar, toplumun etnik ve dini kimliğini tehdit altında bırakabilir. ${ }^{28}$

Yöntemlerin İslâmî rivayetler üzerinde kullanılamayacağına dair dile getirilen bir argüman ise geleneklerin Tanrı anlayışındaki farklılıklar ile Kitab-ı Mukaddesle İslâmî rivayetlerin yapıları, işlevleri, serüvenleri açısından var olan farklılıklardır. ${ }^{29}$ Bir diğer gerekçe bu yöntemlerin, dini metinler ile uyuşmayacak felsefî arka planlara sahip olduklarıdır. Bu yöntemler Kitab-1 Mukaddes geleneğinden

26 Fatma Kızıl, “Avrupamerkezciliğin Bir Yansıması Olarak Oryantalist Söylem: Kültürel Ödünç Alma Kavramı”, Insan ve Toplum 3/6 (2013): 323.

27 Tahsin Görgün, "Yeni Anlama ve Yorumlama Yöntemlerinin F1kıh Usulüne Göre Durumu” Fikıhta Usul Meselesi (İstanbul: 2013), 682.

28 Abdulvahab Messiri, (ed.) Önyargı (İstanbul: Mahya, 2015), 14.

29 Bu ayrıntılar için bk. Altıntaş, Tarihsel Eleştiri Yöntemlerinin Tenkidi ve İslâmî Rivayetlere Uygulanması Sorunu, 241-243. 
Tarihsel Eleştiri Yöntemlerinin İslami Rivayetlere Uygulanma İmkânına Dair... aktarıldığı için, Hıristiyan Orta Çă̆'ının klasik Katolik "yöntem”i İslam dünyası için "yeni" dir. ${ }^{30}$ Yine bu görüşü savunanlara göre, bu yöntemler İslam dünyasına ait otantik bir refleks kabul edilemez. Bu yöntemler Müslümanların kendi kaynaklarına yaklaşımları neticesinde ortaya çıkan bir şüphe durumundan doğmuş değildir ve bu yöntemlerin kullanılması tabiî bir sürecin neticesinde değil yapay süreçlerin ve zihnî bir motivasyonun neticesinde olmuştur. Bu durumda, bu yöntemlerin İslâmî rivayetlere uygulanması, klasik İslâmî ilimlerin günümüzde mirasçısı ve Kur'ani yaklaşımın temsilcisi gibi görülen tefsir, hadis gibi disiplinlerin bile pozitivist felsefenin gittikçe derinleşen etkisi altına girmesi demek olacaktır. ${ }^{31}$ Yöntemlerin İslâmî rivayetlere uygulanması konusundaki karşı çıkışın bir diğer gerekçesi, yöntemlere dair bilgi eksikliği ile yöntemlerle meşguliyetin Müslümanların fikir ve düşünce dünyalarını farkında olmadan da olsa etkileyeceği endişesidir. ${ }^{32}$

Bu görüşe karşılık, yöntemlerin farklı metinler üzerinde kullanulabileceğine dair dile getirilen en temel argüman ise tarihsel eleştiri yöntemlerinin her türlü metne uygulanabilecek evrensel yöntemler olduğudur. Buna göre, yöntemlerin kullanım amaçları, başka her türlü metin üzerinde kullanılmasını mümkün kılacak özelliklere sahiptir. Yöntemlerin hem metnin orijinalinin tespit edilmesi hem de metnin asıl anlamının anlaşılıp yorumlanması noktasındaki katkısı İslâmî rivayetlerle ilgili önemli sonuçlar vaad edebilir. Yöntemlerin farklı metinler üzerinde kullanılabileceği yönünde dile getirilen diğer bir argüman, İslam geleneği ile Yahudi-Hıristiyan geleneğinin Tanrı anlayışındaki benzerlikler ile Kitab-1 Mukaddesle İslâmî rivayetlerin yapıları, şifahi karakteri, işlevleri, serüvenleri açısından benzerliklerdir. Diğer bir gerekçe bu yöntemlerin farklı bir gelenek tarafından üretilmiş olsa bile köklü bir geleneğin yansıması olmaları sebebiyle, yöntemlerin uygulanmasının kategorik olarak imkânsız kabul edilemeyeceğidir. Ayrıca bu görüşe göre, bu yöntemleri görmemezlikten gelmek kültürel ortamdaki etkisini zayıflatmaz. Zira

30 Görgün, "Yeni Anlama ve Yorumlama Yöntemlerinin Fıkıh Usulüne Göre Durumu", 675.

31 Burhaneddin Tatar, "Günümüz İlahiyat Fakültelerinde Tefsir, Hadis, Ahlak Felsefesi Ve Müzik Derslerinin Anlamı Üzerine Notlar”, Süleyman Demirel Üniversitesi Ilahiyat Fakültesi Dergisi 1/30 (2013): 85.

32 Özcan Hıdır, “Oryantalizme Karşı Oksidentalizm: Hadis Oksidentalizmi”, Hadis Tetkikleri Dergisi 5/1 (2007): 12-15. 
başka gelenekler tarafından üretilen yöntemlerle etkileşim kaçınılmazdır, hiçbir yöntem ve düşünce tamamen özgün olamaz. Bunun için bu tür yeni metodolojik araçlarla korkuya kapılmadan yüzleşmek gerekir. ${ }^{33}$ Ayrıca bu yöntemlerin İslam lehine kullanılması da ihtimal dairesinde olduğu için kullanılabilir bulunmaktadır.

Yöntemlerin İslâmî rivayetler üzerinde uygulanmasının imkânı ile imkansızlığına dair dile getirilen argümanlara bakıldığında taraflar arasındaki ayrılığın -bir tarafın gelenekler arasındaki benzerlikler üzerinde dururken diğerinin farklılıklar üzerinde durması gibi- daha çok belli noktalardaki bakış açısı farklılığına dayandığı görülür. Yöntemlerin İslâmî rivayetler üzerinde asla kullanılamayacağını savunanların dile getirdikleri gerekçelerin büyük kısmı, yöntemlerin Kitab-1 Mukaddes üzerindeki uygulamalar ile Oryantalistlerin uygulamalarından bağımsız olarak düşünülemediğine işaret etmektedir. Bu açıdan, yöntemlerde yapı olarak var olduğu kabul edilebilecek evrensel yönler, oryantalistlerin uygulamalarının ve kutsal kitap tenkidinin gölgesinde kalmıştır.

Yöntemlerin İslâmî rivayetler üzerinde uygulanmasının imkanı ile ilgili karar verebilmek için öncelikle yöntemlere yöneltilen eleştirilerle yüzleşmek gerekmektedir.

\section{Tarihsel Eleştiri Yöntemlerine Yönelik Dile Getirilen Eleştiriler}

Tarihsel eleştiri yöntemlerine ve bu yöntemlerin kutsal metinlere uygulanmasına, bizzat içinden doğduğu Batı dünyasından birçok eleştiri yöneltilmiştir. Bunlar arasında yöntemlerin ön kabullerine, yöntemler kapsamında kullanılan argümanlara, yöntemlerin uygulayıcılarına ve uygulanışına, güvenilirliğine ve yol açtığı sonuçlara dair çeşitli eleştiriler mevcuttur.

Tarihsel eleştiri yöntemlerinin ön kabulleriyle ilgili eleştirilerden ilki pozitivist ön kabullerle hareket ettiğidir. Şüphecilik (İng:

33 Ömer Özsoy, "Kur'an ve Tarihselcilik Tartışmasında Gözden kaçırılanlar", Tezkira 1997,c. 11-12, s. 70; Salih Özer, "Hadis Metninin Anlaşılmasında Diğer Metinlere Referansların Önemi ya da Hadiste Metinlerarasılık ve Metinlerarası Okuma", Dinbilimleri Akademik Araştırma Dergisi 8/4 (2008): 323. 
TarihseI Eleştiri Yöntemlerinin İslami Rivayetlere Uygulanma İmkânına Dair... skepticism) ${ }^{34}$ ve ihtimal ilkesi (İng: Probability) ${ }^{35}$, olayların katı nedensellik (İng: Causality) ilkesi çerçevesinde açıklanması, ilerlemecilik (İng: Progressivism) ve gelişimsellik ilkesinin metinlerle ilgili kabullerde de yer alması ve akıl ile bilimin yegâne ölçü kabul edilmesi burada dile getirilebilecek ön kabullerdir.

"Şüphecilik", tarihsel eleştiri yöntemlerinin temel aksiyomları arasında yer alır. Buna göre dini rivayetler de dâhil her şeye şüphe ile yaklaşmak gerektiği ve tarihin ihtimallerden oluştuğu üzerinde durulur. ${ }^{36}$ Burada metodik bir şüphe kast edilse de tarihsel eleştiri yöntemlerinin uygulamalarında metodik şüphe yerine radikal boyutlarda septiklik görülür. Bu durum, yöntemin ön kabulünden ziyade bu kabulün uygulamalara yanlış aktarılması ile alakalıdır. Ayrıca tarihsel eleştiri yöntemleri, kendisi dışında her şeye olduğu gibi kendi yöntemine ve sonuçlarına da şüphe ile yaklaşabilmesi gerekirken bunu yapmamaktadır. Tarihsel eleştiri yöntemleri için "ihtimal ilkesi" mühim olduğu için, olayların kesinliği gibi bir durum söz konusu değildir. Bu açıdan, tarihsel eleştiri yöntemlerinin uygulamalarında, "ihtimal ilkesi" nin septikliğe doğru kaydığı söylenebilir. ${ }^{37}$ Yine tarihsel eleştiri yöntemlerinin ön kabulleri arasında yer alan "katı nedensellik ilkesi", bağlantı, analoji ve doğaüstü olayları/durumları ret ilkelerinden hareket eder. "Nedensellik yasası", her olayın bir nedeni olduğunu kabul eder. Aynı zamanda nedenle etki arasındaki bağlantının zorunluluğu üzerinde durur. ${ }^{38}$ Yani evrendeki her şeyin bir nedeni vardır ve aynı nedenler aynı koşullar altında aynı sonucu verdiği kabul edilir. Burada nedensellik ilkesinin farklı yorumları olduğunu hatırlatmak gerekir. Nedensellik tarihsel eleştiri yöntemlerinin uygulamalarında genellikle görüldüğü şekilde, katı olabilir. Mekanik bir dünya tasavvurunun yansıması

34 Epistemoloji alanında kuşkuculuk bilginin imkânsız olduğunu ya da hiçbir şeyin temellendirilemeyeceğini savunur. Bu manadaki şüphecilik 1lımlı ya da radikal gibi farklı düzeylerde olabilir. Ahmet Cevizci, Felsefe Sözlüğü (İstanbul: Paradigma Yayınları, 2000), 583.

35 İhtimal ilkesine göre, bizim geçmişte olduğunu düşündüğümüz olaylara dair bir kesinlik yoktur. Tarihsel eleştiri yapan kişi, hiçbir zaman kesin bilgiye erişemez. İhtimallerin yüksek ya da daha düşük seviyede olması söz konusudur I. Howard Marshall, New Testament Interpretation: Essays on Principles and Methods, (Grand Rapids: Eerdmans, 1977), 131.

36 Edgar Krentz - Gene M. Tucker, The Historical-Critical Method (SPCK, 1975), 55.

37 William Bell Riley, The Finality of Higher Criticism: or, the Theory of Evolution and False Theology (Taylor \& Francis, 1988), 30.

38 Bedia Akarsu, Felsefe Terimleri Sözlüğ̈̈ (Türk Dil Kurumu Yayınları, 1998), 132. 
olan katı nedensellik, olayların nedenlerinin yine fizik dünyada olduğunu iddia eden determinizmin (belirlenimcilik) ${ }^{39}$ yolunu açar. ${ }^{40}$ Her şeyin bir sebep sonuç bağlantısı içerisinde ele alındığı determinist bir yaklaşım daha çok tarihselliğin pozitivist formlarında yaygin görülür. ${ }^{41}$

Sebep-sonuç ilişkisine vurguda bulunmak olarak açıklanabilecek "bağlantı ilkesini" (İng: Correlation), bir olayın düzenli ve sürekli bir biçimde başka bir olaya yol açması biçiminde tanımlamak mümkündür. Bağıntı ilkesine göre, olaylar ancak sebep-sonuç ilişkisi içerisinde anlaşılabilir. ${ }^{42}$ Sebep sonuç ilişkisinin aşırı ön plana alınması, dini metinlerde, olayların birçoğu beşerî olmayan nedenlere bağlanması nedeniyle problem oluşturmaktadır. ${ }^{43}$ Ayrıca kutsal metinlerin yalnızca sebep-sonuç ilişkisi içerisinde ele alınması metnin ilâhî yönünü geri plana atmaya neden olabilir. ${ }^{44}$ Sebep-sonuç ilişkisi tarihî olayların ve olguların anlaşılması için önemli bir veridir. Fakat sebep-sonuç ilişkisini katı bir kural olarak görmek, olayların anlaşılmasını sebep-sonuç bağlantısına indirgemek bu ilkeyi olayların anlaşılmasında faydalı değil kısıtlayıcı hale getirebilir.

"Analoji ilkesi" 45, geçmişin, şu anda yaşananları düşünmek yoluyla yeniden inşa edilebileceği üzerinde durur. Buna göre tarih, sebep sonuç ilişkisi içinde kapalı bir süreçtir. Buradaki aksiyom ise

39 Determinizm evrende olup biten her şeyin bir nedensellik bağlantısı içinde gerçekleştiğini, fiziksel evrendeki ve dolayısıyla da insanın tarihindeki tüm olgu ve olayların mutlak olarak nedenlerine bağlı olduğunu ve nedenleri tarafından koşullandığını savunur. Akarsu, Felsefe Terimleri Sözlü̈̆̈̈̈, s. 30; Cevizci, Felsefe Sözlï̆g̈̈, 240.

40 Mehmet Evkuran, "İslam Düşüncesinde Nedensellik Problemi Doğa ve Tarih Algımı Üzerine", Eskiyeni Anadolu Ilahiyat Akademisi Araştırma Dergisi 21 (2011): 18.

41 Krentz - Tucker, The Historical-Critical Method, 58.

42 David Alan Black - David Dockery (eds.), New Testament Criticism and Interpretation (Michigan: Zondervan Pub. House, 1991), 84.

43 Ian Henderson, "Rudolf Bultmann", Ankara Üniversitesi Illahiyat Fakültesi Dergisi, çev.: Mehmet Dağ 29 (1987): 161.

44 Gerhard Maier, The End of the Historical-Critical Method (Concordia Publishing House, 1977), 19.

45 Analoji, var olan şeyler arasındaki özellikle sınıf dışında kalan işlev benzerliği, ilişki benzerliğine işaret etme işlemi ve iki şey arasındaki benzerliklerden yola çıkarak onların başka bakımlardan da benzer olacaklarını öne süren çıkarsamadır. Cevizci, Felsefe sözlüğü̈, 50. 
Tarihsel Eleştiri Yöntemlerinin İslami Rivayetlere Uygulanma İmkânına Dair... doğanın, toplumun ve insanın genel olarak çok büyük değişim geçirmeyecek şekilde bir benzerlik içinde olduğudur. ${ }^{46}$ Analoji ilkesinin yansımalarından birisi "anti-supernaturalism" olarak da ifade edilen mucize ve doğaüstü olayların kabul edilmemesidir. Bu kabule göre, bugün doğaüstü olaylar yaşanmıyor ve görülmüyorsa geçmişte de görülmüş olmamalıdır. ${ }^{47}$ Tarihsel eleştiri yöntemlerini uygulayanlar, metne bir tarihçi gibi yaklaştıkları için, Aydınlanma ile gelen Deizm'in ve Newton fiziğinin de etkisiyle doğaüstü durumlara (mucizeler, vahiy, ilham vb.) pirim vermemektedirler. ${ }^{48}$ Tarihsel eleştiri yöntemleri tarafından doğaüstü alanın kabul görmemesi, esasında pozitivizmin bir yansımasıdır. Zira pozitivizme göre, bu alan denetlenebilir ve doğrulanabilir olmadığı için bilimsel kabul edilemez. ${ }^{49} \mathrm{Bu}$ yaklaşımın devamı niteliğinde, tarihsel eleştiri yöntemleri doğaüstü olayları ve bunların geçtiği metinleri bilimsel kabul etmemektedirler.

Evrenin ana gerçeğinin devamlılık ve kalıcılık değil değişme olduğu üzerinde duran "ilerlemecilik fikri, ${ }^{50}$ tarihsel eleştiri yöntemlerinin ilkelerinden bir diğeridir. Buna göre, olaylarda, fikirlerde, metinlerde ve tarihin bütün tezahürlerinde basitten gelişmişe doğru bir ilerleme ve bir gelişme vardır. Bu kabule göre bu durum dini metinlerde olduğu gibi dini düşüncenin gelişiminde de etkilidir. Oysa dini metin ve düşüncede zaman zaman bir ilerlemenin var olduğunu söylemek mümkünse de gerilemelerin görülmesi de doğaldır. Yani ilerleme, katı ve kesin bir kural olmaktan ziyade doğal bir sürecin yansımasıdır.

Tarihsel eleştiri yöntemleri, aklı merkeze alarak geleneğin ön yargılarına karşı salt aklın metodolojik bakımdan disipline edilmiş kullanımının öne çıkarılması gerektiği üzerinde durur. Tarihsel

\footnotetext{
46 Krentz - Tucker, The Historical-Critical Method, 57.

47 Stephen R. Haynes - Steven L. McKenzie, To Each Its Own Meaning: An Introduction to Biblical Criticisms and Their Application (Westminster John Knox Press, 1993), 13.

48 Bart D Ehrman, The New Testament: A Historical Introduction to the Early Christian writings (New York: Oxford University Press, 2000), 13.

49 Popper, "Sunuş", 9.

50 Cevizci, Felsefe sözlüğ̈̈, 496.
} 
eleştiri yöntemleri Aydınlanma'nın ürünü olan aklı ön plana çıkarırken aynı zamanda, bu aklı imanın önüne geçirir. ${ }^{51}$ Aklın, doğru ile yanlışın ayırt edilmesindeki işlevi açıktır. Fakat akıl ve rasyonalite gibi kavramlara yapılacak vurgunun miktarı ya da bunların ne ölçüde bilimsel olduğu tartışılabilir. Bilimsel bilgiye aşırı değer yüklemek de bu yöntemlerin eleştirilen ön kabullerindendir. Bilimin ulaşılabilecek bütün gerçekliklerin tek ölçüsü sayılması, Aydınlanma'nın önemli bir özelliğidir.

Yöntemlerin Kitab-1 Mukaddes yazarlarına ve kiliseye yönelik de ön kabulleri mevcuttur. Yazılı metinler, yazıya geçirilmemiş şifahi rivayetlere göre daha üstün kabul edilir. Çünkü olay ile olayın yazıya aktarımı arasındaki zaman aralığının, kaynağın ve içerdiği bilginin güvenilirliği ile ters orantılı olduğu düşünülür. Bu kabul, kutsal kitabın şifahi karakterinin görmezden gelindiği şeklinde yorumlanabilir. Metinlerle ilgili diğer bir ön kabul uzun süre sadece şifahi olarak aktarıldığına dairdir. ${ }^{52}$ Ayrıca Kitab-1 Mukaddes'in tamamen insan ürünü olduğu ve zaman içinde değiştiği, korunmaya çalışılmadığı̆, metnin yazarlarının metin kaydedip korumaya çalışmaktan ziyade metinleri üreten ve her birinin kendi stilinde, terminolojisinde ve perspektifinde diğer yazarlardan farklı tarza sahip kişiler olduğu düşünülür. Bu sebeple de diğer metinlere uygulanan tarafsız ve ön yargısız metotların bu metinler üzerinde uygulanabileceği kabul edilir. ${ }^{53}$ Metinlerdeki uyumsuzluklar, tutarsızlıklar ve çelişkiler doğrudan -uydurulma veya farklı bir kaynağa indirgenme- dişında bir çözüme kavuşturulmaz.

Yöntemler kapsamında kullanılan argümanlara da çeşitli açıdan eleştiriler getirilmektedir. Tarihsel eleştiri yöntemlerinin filolojik argümanları yoğunlukla kullanması dile dair konuların kaygan bir zemin üzerinde olduğu, belli sabitelerin olmadığı ve bu sebeple

51 Maier, The End of the Historical-Critical Method, 10; Alvin Plantinga, "Warranted Christian Belief: The Aquinas/Calvin Model", The Rationality of Theism (Springer, 1999), 386.

52 Bu ön kabul, İsa döneminde de az miktarda da olsa, materyallerin yazıya geçirilmiş olması ihtimali bulunduğu iddiasıyla eleştirilmiştir. Bk. Marshall, New Testament Interpretation, 159.

53 Albert E Avey, Historical Method in Bible study, (New York: C. Scribner's Sons, 1924), 16; Normal L. Geisler, “Beware of Philosophy: A Warning to Biblical Scholars", Journal-Evangelical Theological Society 42 (1999): 14. 
Tarihsel Eleştiri Yöntemlerinin İslami Rivayetlere Uygulanma İmkânına Dair...

de bir ölçüt kabul edilemeyeceği gerekçesiyle ${ }^{54}$ eleştirilmektedir. Yöntemler uygulanırken sıkça atıfta bulunulan anakronizm ${ }^{55}$ metinlerdeki yanlışlıkların tespiti için önemli bir yöntem olsa da hatadan uzak değildir. Anakronizm, ancak tamamiyla insan ürünü olan metinler ve eserler üzerinde uygulanabilir. ${ }^{56}$ Ayrıca anakronizmin son dönemlerde özensizlik ve bilgisizlikten kaynaklanan bir tarih yanılgısı olarak görülmek yerine, tarih yazımında karşılaşılan ve kaçınılmaz olan bir durum olduğuna dair tartışmalar görmek mümkündür. ${ }^{57}$ Yine uygulamalar esnasında sıkça atıfta bulunulan "argumentum e silentio"'1n (Lat: argumentum e $(x)$ silentio; Ingilizce: Argument from Silence $)^{58}$ güvenilir olup olmadığ 1 konusu tartışmalıdır. ${ }^{59}$

Yöntemlere, uygulayıcılarının durumları ile ilgili olarak da eleştiriler yöneltilmiştir. Özellikle yöntemlerin ilk uygulayıcılarının daha çok ideolojik bir araç olarak kullanması, kutsal kitap tenkidindeki birikimleri sebebiyle yönetmeleri kutsal kitap tenkidi çerçevesi içinde kullanmaları, rivayetler üzerinde uygularken metnin özüne

R. Norman Whybray The Making of the Pentateuch: A Methodological Study (Bloomsbury Publishing, 1987), 130.

55 Anakronizm, olayların gerçek düzeniyle anlatılma ve aktarılma düzeni arasındaki farklılık ve tutarsızlık; bir şeyin bir kavram veya olayın gerçek tarihsel bağlamı dışına çıkarılması; bir olayı yanlış bir tarihe ya da çağa yerleştirmekten kaynaklanan yanılg1 manalarına gelir. Cevizci, Felsefe Sözlü̆ğ̈̈, 45; John Anthony Cuddon, Dictionary of Literary Terms and Literary Theory (John Wiley \& Sons, 2012), 33; Büyük Larousse, "Büyük Larousse Sözlük ve Ansiklopedisi" II (İstanbul: Gelişim Yayınları AŞ., 1986), 578.

Zenos, The Elements of the Higher Criticism, 74.

57 Bart Raymaekers, Lectures for the XXIst Century (Leuven University Press, 2008), 176.

58 Türkçe'de sükut delili olarak ifade edilen bu argüman, bilindik bir kaynağın bir şeyi, olayı veya durumu zikretmemesini o şeyin, olayın veya durumun gerçek olmadığı ya da gerçekte yaşanmadığı şeklinde yorumlanmasına yarayan bir çeşit akıl yürütme yöntemidir. Bu sebeple, bir şeyin varlığı gibi yokluğunun da bir şeyler anlattı̆̆ kabul edilir. Timothy McGrew, "The Argument from Silence", Acta Analytica 29/2 (2014): 215; Zenos, The Elements of the Higher Criticism, 75.

59 Argumentum e silentio, kimilerine göre güvenilir; kimilerine göre en iyi ifadeyle zayıf, tehlikeli veya değersizdir. Kimilerine göre ise çok dikkatli şekilde, güvenilirlik zafiyetini de göz önünde tutarak ve ancak belli şartlarda kullanılması mümkün olabilir. Bu konudaki tartışmalar için bk. Altıntaş, Tarihsel Eleştiri Yöntemlerinin Tenkidi ve İslâmî Rivayetlere Uygulanması Sorunu, 204-210. 
dair herhangi bir hassasiyete sahip olmamaları ve yöntemleri uygulayan kişiler arasında hem yöntem hem sonuç olarak bir ortaklık olmaması dile getirilen diğer eleştiri noktalarıdır. ${ }^{60}$

Yöntemlerin sübjektifliği, uygulayıcıların ön kabulleri, kişisel tercihleri ve ideolojilerinin uygulamalara yansıdığı da diğer bir eleştiri noktasıdır. Ayrıca yöntemlerin uygulanışında çeşitli tutarsızlıkların bulunduğu, tatmin edici olmayan sonuçlara ulaştırdığı, metnin içindeki her şeyi kendi iddiasına uygun şekilde anlamaya çalıştığı, modern paradigmalar kullandığı, genellemeci olduğu, sadece belli kesimlere (batılı, erkek) hitap ettiği, yöntemlerin birbirine dayandığı ve yöntemlerin zaten yapabileceği her şeyi yaptığı öne sürülen diğer eleştiri noktalarıdır. Yöntemlerin dini metinler üzerinde kullanılmasının metinlerin teolojik anlamının geri planda kalmasina sebep olduğu, okuyucuyu metinden uzaklaştırdığı, metinlere olan güveni azalttığı ve metni itibarsızlaştırdığı yönünde eleştiriler de dile getirilmektedir. ${ }^{6}$

\section{Yöntemlerin İslâmî Rivayetler Üzerinde Kullanımına Has Eleşti- riler}

Yöntemlerin İslâmî rivayetler açısından imkânı hakkında konuşmak için tarihsel eleştiri yöntemlerinin metodolojisine ve Kitab-1 Mukaddes üzerindeki kullanımına yönelik yukarıda işaret edilen eleştirilerle birlikte, yöntemlerin İslâmî rivayetler üzerinde kullanılmasına has eleştirileri de görmek gerekir. Yöntemlerin İslâmî rivayetler üzerindeki kullanımına yöneltilen eleştiriler hem Oryantalistlerden hem de Müslüman ilim adamlarından gelmektedir. Oryantalistlerin, yöntemlerin İslami rivayetler üzerindeki uygulamalarına yönelik tenkitleri, yöntemlerin daha verimli şekilde nasıl kullanılabileceğine dairdir. Müslümanlardan gelen eleştiriler ise genellikle yöntemlerin metodolojilerine yönelik eleştirilerden ziyade tekil örneklere yönelik sınırlı bir reaksiyon ile oryantalizmin geneline yönelik eleştirilerden müteşekkildir.

Tarihsel eleştiri yöntemlerinin İslâmî rivayetler üzerinde uygulanmasına yönelik eleştiriler yukarıda yöntemlerin geneline yönel-

60 John Rothra, "Critique of Higher criticism" (John Rothra Ministries, 2006), 9; Black - Dockery, New Testament Criticism and Interpretation, 25.

61 John Ziesler, "Historical Criticism and a Rational Faith", The Expository Times, 105/9 (1994): 272; Maier, The End of the Historical-Critical Method, 21-22; Law, The Historical-Critical Method, 20, 218-219, 223. 
Tarihsel Eleştiri Yöntemlerinin İslami Rivayetlere Uygulanma İmkânına Dair... tilen eleştirilerde olduğu gibi yöntemlerin ön kabullerine, yöntemler kapsamında kullanılan argümanlara, yöntemlerin uygulayıcılarına ve uygulanışına, güvenilirliğine ve yöntemlerin yol açtığı sonuçlara dair olanlar şeklinde gruplandırılabilir. Bu eleştirilerin, yukarıda ayrıntılı olarak değindiğimiz, Batı geleneğinin yöntemlerin metodolojilerine yönelttiği eleştiriler ile uyumlu olduğu görülür. Yani oryantalistlerin eleştirileri, yöntemlerin metodolojik açıdan eleştirilen noktalarının İslâmî rivayetlerdeki yansımaları kabul edilebilir.

Yöntemlerin ön kabulleri ile ilgili olarak, yöntemlerin İslâmî rivayetlere uygulanışı noktasında şüpheciliğin ılımlı bir şüphecilikten ziyade kaynaklara, râvilere, müelliflere, kaynakların müelliflere nispetine karşı zaman zaman septik boyuta kayan bir şüphecilik ile genel bir güvensizlik görülür. Yine ön kabullerin etkisi ile olaylar katı nedensellik ilişkisi içerisinde anlaşılmaya çalışılır ve bütün olaylar sadece toplumsal şart ve gelişmelerin neticesi kabul edilir. Bu ön kabul, aynı zamanda rivayetlerin tarihlendirilmesi çalışmalarında ve hadislerin farklı grupların birbirleri ile çatışmaları neticesinde ortaya çıktığını savunan görüşlerde de görülmektedir. ${ }^{62}$ İlerleme ve gelişimsellik ön kabulüne göre ise metinlerde ve hatta dini düşüncede bir ilerleme ve gelişimsellik mevcuttur. Bu kabul yoğunlukla metinlerin ortaya çıkış ve gelişimine dair yapılan tarihlendirme ile ilgili çalışmalarda belirgindir. Yöntemlerin eleştirilen ön kabullerinden bir diğeri akla ve bilime yüklediği aşırı önemdir. Burada akıldan kasıt Aydınlanma sonrasındaki anlamıyla akıldır. Bilgi ise emprizm, rasyonalizm ve pozitivizmin izlerini taşıyan "bilimsel bilgi" dir. Bunlarla birlikte İslâmî rivayetlerin metin ve râvilerine has ön kabuller görmek de mümkündür. Mesela yazılı metinlerin şifahi metinlere göre daha korunmuş, bozulmamış olduğu; bu sebeple de yazıya aktarımı hemen gerçekleşmemiş olan ve uzun süre sadece şifahi olarak aktarıldığı düşünülen İslâmî metinlerin bozulmuş olma ihtimalinin yüksek olduğu genel kabul görür. ${ }^{63}$ Râvilerin tutarsız ve uyumsuz malzeme aktarımında bulunmaları, yöntemlerin genel kabulüne göre ya uydurma ya da râvi kaynaklı (kasıtlı) değiştirme emaresi olarak kabul edilir. Yine metinlerle ilgili olarak İslâmî

62 Örnekler için bk. Altıntaş, Tarihsel Eleştiri Yöntemlerinin Tenkidi ve İslâmî Rivayetlere Uygulanması Sorunu, 307.

63 Bu kabullere karşı çıkan Nabia Abbot ve Gregor Schoeler gibi isimler görmek mümkündür. Ayrıntılı bilgi için bk. Altıntaş, Tarihsel Eleştiri Yöntemlerinin Tenkidi ve İslâmî Rivayetlere Uygulanması Sorunu, 324. 
rivayetlerde içerik tenkidi yapılmadığı ve sadece sened tenkidi üzerinde durulduğu; isnatların (tümünün ya da bir kısmının) güvenilmez olduğu; İslâmî rivayetlerin büyük kısmını Yahudi ya da Hıristiyan menşeli olduğu da kabuller arasında zikredilebilir.

Tarihsel eleştiri yöntemlerinin İslâmî rivayetler üzerinde uygulanması kapsamında kullanılan argümanlara bakıldı̆̆ı zaman, filolojik argümanlara, anakronizme ve "argumentum e silentio" ya aşırı değer yüklendiği görülür. Yöntemi uygulayanlara yönelik ise özellikle ilk uygulayıcılar olan oryantalistlerin yöntemleri ideolojik bir araç olarak kullandığı dile getirilebilir. Eski Ahit, Yeni Ahit ve filoloji konusunda özel eğitimleri olan bu isimlerin bir kısmı, alanın özüne dair bir hassasiyete sahip değildirler. Yöntemlerin güvenilirliği konusunda ise yöntemlerin sübjektifliği, ideolojik olduğu, genel kabul gören ve tatmin edici sonuçlara ulaşmadığı, tutarsızlıklar barındırdığ rülmektedir. 64

Yöntemler oryantalistler tarafından özellikle metinlerin tarihlendirilmesi amacıyla kullanılmış, birçok kez de spekülatif yorumlarla süslenmiş sonuçlar ortaya konulmuştur. Metinlerin yorumlanması konusunda ise bu yöntemlerin metinlerin tarihselliği üzerinde yaptıkları vurgu, İslâmî rivayetler üzerinde kullanımları açısından dikkat gerektirmektedir. Zira metinleri tarihsel şartlarını, metnin zamanı, mekânı ve dönemin şartlarını dikkate alarak değerlendirmek (İng: contextualisation) ile metni tarihsel bağlama indirgemek (İng: Contextualism) farklı iki tavırdır. ${ }^{65}$ İslâmî metinler, genel olarak hem tarihsel hem de metafiziksel iki ayrı yöne sahiptir. Kur'an (ve vahiy kontrolündeki Hz. Peygamber'den sâdır olması açısından hadisler), hem tarihsel hem metafizik boyuta sahip olmaları hasebiyle, paradoksal olarak bir yanları kavranabilir ve tarihseldir. Diğer yanları ise metafiziktir. Bu sebeple, metinleri sadece tarihsel boyuta hapseden, olguyu, zamanı, mekânı ve olayın arka planını ön plana çıkaran yaklaşımlar olayların metafizik boyutunun gözden kaçmasına sebep olabilir. Tarihsel bir olay, tarih ufku içinde kısmen kavranabilir olsa da aynı zamanda metafiziksel ufuk açısından ele alın-

64 Ayrıntılı bilgi ve örnekler için bk. Altıntaş, Tarihsel Eleştiri Yöntemlerinin Tenkidi ve İslâmî Rivayetlere Uygulanması Sorunu, 355-364.

65 Bülent Şenay, "Yahudi-Hıristiyan İlişkileri Tarihi ve Antisemitizm-Oryantalizm İlişkisi”, Uludă̆ Üniversitesi İlahiyat Fakültesi Dergisi 11/2 (2002): 138. 
Tarihsel Eleştiri Yöntemlerinin İslami Rivayetlere Uygulanma İmkânına Dair... ması gereken bir boyutu vardır. Bu sebeple, İslam düşünce geleneğindeki yaklaşım, modern düşüncenin olguyu ön plana çıkaran, zaman ve mekânı hareket noktası olarak seçen yaklaşım ile uyumsuz bir düşünce tarzına sahiptir. ${ }^{66}$

Hem yöntemlerin geneline yönelik hem de yöntemlerin İslâmî rivayetler üzerindeki uygulamalarına has olan tüm bu eleştiriler göz önünde bulundurulduğunda, tarihsel eleştiri yöntemlerinin İslâmî rivayetler üzerinde kullanımıyla ilgili iki ihtimalden bahsedilebilir. İlk ihtimal yöntemlerde hiçbir değişiklik yapılmadan olduğu gibi İslâmî rivayetler üzerinde kullanılmasının mümkün olduğu kabulüdür. Fakat bir yöntemler manzumesinin ortaya çıktığı ortamdan, şartlardan, paradigmadan, yöntemleri oluşturan ön kabul, sonuç veya ideolojilerden tamamen bağımsız şekilde düşünmek mümkün değildir. Zira bu durum dikkate alınmadığında, oryantalistlerin gerçekleştirdiği ilk uygulamalarda da görüldüğü üzere, yöntemlerin uygulanışının olumsuz bir tecrübeye dönüşmesi kaçınılmazdır. Bu durum üzerinde ayrıca İslâmî rivayetler üzerinde uygulama yapan isimlerin Eski ve Yeni Ahit eğitimi almış kişiler olması sebebiyle yöntemlerin Kutsal Kitap tenkidi çizgisi dışına çıkamamasının da etkisi olmuştur.

İkinci ihtimal ise yöntemlerden belli şartlarda istifade edilebileceği düşüncesidir. Yöntemlerden belli şartlarda istifade edilebileceği düşüncesi hem geleneksel yöntemlerin hem de başka geleneklerin ürettiği metodolojik araçların sonuna kadar, kayıtsız şartsız ve sınırsız şekilde kullanılabileceğini kabul eden bir tür eklektizm haline dönüşürse uygulamaların başarısız olması yine kaçınılmaz olur. Zira bu şekildeki bir kabul bir açıdan hesaplaşma içermeyen bir taklitten ya da basit değişikliklerle gerçekleştirilmeye çalışılan bir adaptasyondan ibaret kalır. İslam dünyasında bu yöntemlerin İslâmî rivayetler üzerinde kullanılmasını gerekli gören ve deneyen Müslüman isimlerin uygulamaları genellikle bu tavır ile maluldür. Yani buralarda ya basit bir adaptasyon tercih edilmiş ya da yöntemlerle tam bir hesaplaşma gerçekleştirilemeden tümden bir metodoloji olarak alınıp rivayetler üzerinde kullanılması yoluna gidilmiştir.

66 Burhanettin Tatar, İslam Düşüncesine Giriş (İstanbul: Dem Yayınları, 2009), 21, 71. Bununla birlikte bu durum, iki farklı düşünme tarzı arasında bir diyaloğun olması imkânsız değildir. Burhaneddin Tatar, "Temel İslam Bilimlerinde Paradoksal Düşünce Tarzı Üzerine”, İslamiyat 6/4 (2003): 17. 
Oysa yöntemlerden belli şartlarda istifade edilebileceği düşüncesine yöntemlerin teorisinin pratik boyutundan farklı olduğunu kabul etmekle başlamak gerekir. Buna göre teorik düzeyde tarihsel eleştiri yöntemlerinin, İslâm düşünce geleneğine uygun olmayan ön kabuller ve uygulamalar içerdikleri teslim edilse dahi dünyanın tümünün bilgi birikimini içeren yönlere sahip olduğu ve yapı olarak bazı açılardan evrensel boyutlara sahip olduğu kabul edilebilir. Fakat bu yöntemler, uygulamalardaki formlar açısından evrensel kabul edilmezler. Bu sebeple yöntemler tamamen bir metodoloji olarak değil de belli yerlerde klasik sisteme katkı sağlayan bir teknikler manzumesi olarak görülebilirler. Bu şekilde, aynı yöntem ile pratikte farklı uygulamalar yapılabileceği kabul edilmiş olur. Bu kabul, yöntemlerin içinden neşet ettiği kültür ile yöntemlerin metinleri üzerinde uygulanacağı kültür arasında bakış farklılığı olduğunu kabul etmemeyi gerektirmez. Fakat bu farklılıkla, basit bir bilgi aktarımı ve düzeltmesi veya bir adaptasyondan ziyade, kabul ve bakışın karşılıklı sorgulanması ile baş edilebilir. Bu şekilde, yöntemlerde dünyaya ait ilmî birikimin yansıması olan evrensel ve metodolojik yönlerin tespit edilip bu kısımların esas alınması mümkün olabilir. $\mathrm{Bu}$ şekilde yöntemler olumlu ve olumsuz yönleri ile toptan kabul edilmediği gibi, toptan da reddedilmiş olmaz.

\section{Sonuç}

Sosyal bilimlerde uygulanan çeşitli yöntemlerin İslâmî rivayetler üzerinde uygulanması, büyük oranda Batı düşünce geleneğinde gelişen ve metodolojik özelliklerini bu gelenekten alan sosyal bilimlerle bugüne kadar geleneksel tenkit yöntemlerini kullanan temel İslâm bilimlerinin yüzleşmesi ve hesaplaşması manasına gelir.

Tarihsel eleştiri yöntemlerinin İslâmî rivayetler üzerindeki uygulanan ilk denemelerinde, uygulayıcıların da etkisi ile Kitab-1 Mukaddes tenkidindeki teolojik çerçeve baskındır. Bu sebeple, bu yöntemlerin Oryantalistlerin uygulama çerçevesi içerisinde İslâmî rivayetler üzerinde uygulanabilir olduğunu kabul etmek mümkün değildir. Zira metinlerin güvenilirliğini içinde bulunduğumuz günden geçmişe doğru tesis etmeye çalı̧maktadır. İslam geleneğinde ise, metinlerin güvenilirliği bilginin nakli ve tespitinde güvenilir râviler esas alınarak geçmişten içinde bulunulan güne doğru yapılır.

İslam dünyasında yöntemlerin rivayetler üzerinde uygulanmasına yönelik yapılan denemeler ya yöntemleri basit bir adaptasyon 
Tarihsel Eleştiri Yöntemlerinin İslami Rivayetlere Uygulanma İmkânına Dair...

ile uygulamış, ya yöntemlerin eleştirilen yönleri ile tam hesaplaşmadan uygulamış ya da tümden bir metodoloji olarak görüp uygulama denemesine kalkmışlar ya da teoride yapılmak istenen şey pratikte başarıya ulaşabilmiş değildir. Bu sebeple İslam dünyasındaki bu uygulanma denemeleri "başarısız” kabul edilebilir. Bununla birlikte İslâm dünyasındaki bu uygulamaların başarısızlığında, yöntemlerin uygulanışıyla ilgili eleştirilen yönlerin tekrar gözden geçirilerek yeniden denenmeye devam edememesi ve karşılıklı etkileşim süreci içerisinde devam etmesi gereken teori-pratik arasındaki uyumsuzlukların çözülememesi de etkili olmuştur.

Kanaatimizce tarihsel eleştiri yöntemleri yapı olarak bazı açılardan evrensel boyutlara sahiptir. Fakat bu yöntemler uygulamalardaki formlar açısından evrensel değildirler. Bu sebeple yöntemleri tamamen bir metodoloji olarak görmek yerine, bir bütün olarak dünyanın tecrübesinin yansımasını içermesi sebebiyle belli yerlerde klasik sisteme katkı sağlayan bir teknikler manzumesi olarak ele almak makul görünmektedir. Bu yaklaşım hem yöntemlerden istifade edebilmek hem de yöntemlere yöneltilen eleştirileri görmezden gelerek kayıtsız şartsız teslim olmamak açısından önem arz etmektedir. Bunun için ayrıca yöntemlerin tam olarak kavranması; yöntemlere yöneltilen eleştirilerin anlaşılması ve bu eleştirilerde ortaya konan genel ve özel sorunların aşılması gerekir. Ayrıca teorik bilgiler ile pratik uygulamalar arasındaki uyumsuzluklar göz önünde bulundurularak pratik uygulama denemelerine devam etmek, yöntemlerin vaad edebilecekleri ile ilgili daha net sonuçlara ulaşmaya yardımcı olabilir. Bu yöntemlerin İslâmî rivayetler açısından başarısı ile ilgili nihai bir değerlendirme yapmak ancak tüm bu şartlara uygun uygulamalar ve empirik çalışmalar yapılmasının neticesinde mümkün olacaktır.

\section{Kaynakça}

Abdulvahab Messiri (ed.), Önyargı. İstanbul: Mahya, 2015.

Akarsu, Bedia. Felsefe Terimleri Sözlüğ̈̈. Türk Dil Kurumu Yayınları, 1998.

Aktay, Yasin. "Kur'an Tarihselciliğine Bir Soykütügü (Geneology) Denemesi". Kur'an ve Tarihselcilik Sempozyumu. 30-36. İstanbul: KURAV, 2000.

Altıntaş, Fatma Betül. Tarihsel Eleştiri Yöntemlerinin Tenkidi ve İslâmî Rivayetlere Uygulanması Sorunu. Doktora Tezi, Erciyes Üniversitesi, 2019.

Arkoun, Mohammed. İslam Üzerine Düşünceler. Çev. Hakan Yücel. İstanbul: Metis Yayınları, 1999. 
Aune, David E. The Blackwell Companion to the New Testament. John Wiley \& Sons, 2010.

Avey, Albert E. Historical Method in Bible Study. New York: C. Scribner's Sons, 1924.

Black, David Alan - Dockery, David (eds.), New Testament Criticism and Interpretation. Michigan: Zondervan Pub. House, 1991.

Brown, Daniel. İslam Düşüncesinde Sünneti Yeniden Düşünmek. Ankara: Ankara Okulu, 2009.

Cevizci, Ahmet. Felsefe Sözlüğü. İstanbul: Paradigma Yayınları, 2000.

Cuddon, John Anthony. Dictionary of Literary Terms and Literary Theory. John Wiley \& Sons, 2012.

Duran, Asım. Aydınlanma ve Kutsal Kitap. Samsun: Üniversite Yayınları, 2017.

Ehrman, Bart D. The New Testament: A Historical Introduction to the Early Christian Writings. New York: Oxford University Press, 2000.

Evkuran, Mehmet. "İslam Düşüncesinde Nedensellik Problemi Doğa ve Tarih Algımız Üzerine". Eskiyeni Anadolu İlahiyat Akademisi Araştırma Dergisi 21 (2011): 17-27.

Fazlıoğlu, Şükran. "Taha Hüseyin". DİA 39. İstanbul: Türkiye Diyanet Vakf1, 2010, 377-379.

Fazlurrahman. Tarih Boyunca İslâmî Metodoloji Sorunu. Çev.: Salih Akdemir. Ankara: Ankara Okulu Yayınları, 1997.

Geçit, Bekir. Erich Rothacker ve Karl R. Popper'de Tarihselcilik Problemi. Doktora Tezi, Mersin Üniversitesi, 2015.

Geisler, Normal L. "Beware of Philosophy: A Warning to Biblical Scholars". Journal-Evangelical Theological Society 42 (1999): 3-20.

Görgün, Tahsin. "Yeni Anlama ve Yorumlama Yöntemlerinin Fıkıh Usulüne Göre Durumu". İstanbul: 2013.

Griffiths, Paul. "Buddhist Jhāna: A Form-Critical Study". Religion 13/1 (1983): 55-68.

Güler, İlhami. “Hasan Hanefî’nin Tecdid Projesi -Tanıtım ve Bir Değerlendirme-". İslâmî Araştırmalar 7/2 (1994).

Hanefi, Hasan. Gelenek ve Yenilenme. Çev. Emin Maşalı. Ankara: Otto Yayınları, 2011.

Hayes, John H - Holladay, Carl R. Biblical Exegesis: A Beginner's Handbook. Atlanta: John Knox Press, 1982.

Haynes, Stephen R. - McKenzie, Steven L. To Each Its Own Meaning: An Introduction to Biblical Criticisms and Their Application. Westminster John Knox Press, 1993.

Henderson, Ian. "Rudolf Bultmann". Çev. Mehmet Dağ. Ankara Üniversitesi Ilahiyat Fakültesi Dergisi. 29 (1987): 145-158.

Hıdır, Özcan. "Oryantalizme Karşı Oksidentalizm: Hadis Oksidentalizmi”. Hadis Tetkikleri Dergisi 5/1 (2007).

John Ziesler. "Historical Criticism and a Rational Faith". The Expository Times 105/9 (1994): 270-274. 
Tarihsel Eleştiri Yöntemlerinin İslami Rivayetlere Uygulanma İmkânına Dair...

Kaldis, Byron. Encyclopedia of Philosophy and the Social Sciences. Sage Publications 2013.

Kızıl, Fatma. "Avrupamerkezciliğin Bir Yansıması Olarak Oryantalist Söylem: Kültürel Ödünç Alma Kavramı”. İnsan ve Toplum 3/6 (2013).

Kotan, Şevket. "Kur'ân'ın Tarihselciliği Tartışması". İslâmî İlimler Dergisi Yayınları, 2007.

Krentz, Edgar - Tucker, Gene M. The Historical-Critical Method. SPCK, 1975.

Kroner, Richard. "Tarih ve Tarihsicilik". Tarih Incelemeleri Dergisi 25/2 (08 Ağustos 2015): 637-643.

Larousse, Büyük. “Büyük Larousse Sözlük ve Ansiklopedisi”. İstanbul: Gelişim Yayınları AŞ., 1986.

Law, David R. The Historical-Critical Method: A Guide for the Perplexed. Bloomsbury Publishing, 2012.

Maier, Gerhard. The End of the Historical-Critical Method. Concordia Publishing House, 1977.

Marshall, I. Howard. New Testament Interpretation: Essays on Principles and Methods. Grand Rapids: Eerdmans, 1977.

McGrew, Timothy. “The argument from silence”. Acta Analytica 29/2 (2014): 215-228.

Özer, Salih. "Hadis Metninin Anlaşılmasında Diğer Metinlere Referansların Önemi ya da Hadiste Metinlerarasılık ve Metinlerarası Okuma". Dinbilimleri Akademik Araştırma Dergisi 8/4 (2008): 305-350.

Özlem, Doğan. "Felsefî Hermeneutiğe Geçiş Yolu Olarak Tarihselcilik”. Ankara Üniversitesi İlahiyat Fakültesi Dergisi 1/40 (1999): 127-145.

Özsoy, Ömer. “Kur'an ve Tarihselcilik Tartışmasında Gözden Kaçırılanlar”. Tezkira 11-12 (1997).

Plantinga, Alvin. "Warranted Christian Belief: The Aquinas/Calvin Model”. The Rationality of Theism. 125-143. Springer, 1999.

Popper, Karl R. "Sunuş". Tarihselciliğin Sefaleti. Çeviren Sabri Orman. 7-17. 1998.

Pormann, Peter E. “Classics and Islam: From Homer to al-Qā'ida”. International Journal of the Classical Tradition 16/2 (2009): 197.

Porter, Stanley E. Dictionary of Biblical Criticism and Interpretation. London; New York: Routledge, 2007.

Raymaekers, Bart. Lectures for the XXIst Century. Leuven University Press, 2008.

Rée, Jonathan - Urmson, James Opie. The Concise Encyclopedia of Western Philosophy and Philosophers. Routledge, 2005.

Riley, William Bell. The Finality of Higher Criticism: Or, the Theory of Evolution and False Theology. Taylor \& Francis, 1988.

Rothra, John. "Critique of Higher Criticism". John Rothra Ministries, 2006.

Soulen, Richard N. Handbook of Biblical Criticism. Louisville: Westminster John Knox Press, 2001. 
Şenay, Bülent. "Yahudi-Hıristiyan İlişkileri Tarihi ve Antisemitizm-Oryantalizm İlişkisi". Uludă̆ Üniversitesi İlahiyat Fakültesi Dergisi 11/2 (2002): 117-146.

Tartı, Nevzat. Tarihsellik Düşüncesi ve Hadislerin Anlaşılması. Ankara: Otto, 2016.

Tatar, Burhaneddin. “Günümüz İlahiyat Fakültelerinde Tefsir, Hadis, Ahlak Felsefesi Ve Müzik Derslerinin Anlamı Üzerine Notlar". Süleyman Demirel Üniversitesi İlahiyat Fakültesi Dergisi 1/30 (2013).

Tatar, Burhaneddin. “Temel İslam Bilimlerinde Paradoksal DüşünceTarzı Üzerine". İslamiyat 6/4 (2003).

Tatar, Burhanettin. İslam Düşüncesine Giriş, Dem yay. Istanbul, 2009.

Whybray, R. Norman. The Making of the Pentateuch: A Methodological Study. Bloomsbury Publishing, 1987.

Williams, Raymond B. "Historical Criticism of a Buddhist Scripture: 'The Mahāparinibbāna Sutta'". Journal of the American Academy of Religion 38/2 (01 Haziran 1970): 156-167.

Yücel, Ahmet. Oryantalist Hadis Literatürü. İstanbul: İfav, 2016.

Zenos, Andrew Constantinides. The Elements of the Higher Criticism. Funk \& Wagnalls Company, 1895. 